\title{
Isolation of Clostridium perfringens from Fecal Sample of Zoo Animals in Iraq
}

\section{Aseel M Hamzah*}

Zoonotic Diseases Unit, College of Veterinary Medicine, Baghdad University, Baghdad, Iraq

\begin{abstract}
In this study the isolated Clostridium perfringens from fecal samples of zoo animals of Al-zawraa Zoo of Baghdad city. A total of 170 fecal samples was aseptically collected from different mammalian species of apparently healthy animals for the isolation and identification of bacterial flora. All the collected samples were inoculated in sheep blood agar media and incubated anaerobically in an anaerobic jar with the gas bag for the study of their cultural properties. Gram's staining, motility test and biochemical tests were also performed for the proper diagnosis of the isolated bacteria.
\end{abstract}

Keywords: Clostridium perfringens; Zoo animals; Fecal samples

\section{Introduction}

Visitor people went to the zoo with their children for entertaining purposes as well as educational [1] although visitor become contact with some animals like monkey, sheep, goat, blue peafowl, zebra foal especially by children and these association make them at risk due to transmission of many zoonotic bacterial diseases like E. coli O157:H7, Salmonellosis, Yersinia, Campylobacter, Mycoplasma and Clostridium spp. [1-4].

Clostridium perfringens is a commensal in the animals gastrointestinal (GI) tract without being associated with disease, as soil and feedstuffs seem to be natural habitats for these organisms [5] although this bacteria is responsible for a spectrum of diseases. $C$. perfringens enterotoxin (CPE) is thought to be an important virulence factor in animals with C. Perfringens-associated diarrhea [6-8]. In contrast, surveys of $C$. perfringens shedding by wild animals are still rare and mainly limited to a few studies in wild animals so the aim of the present investigation was to identify and characterize the Clostridium perfringens in fecal samples of healthy Zoo animals.

\section{Materials and Methods}

\section{Fecal sample}

A total of 174 fecal sample from zoo animals were collected aseptically with wide mouth container and transport the fecal maerial to zoonotic diseases laboratory in collegege of veterinary medicine of baghdad university.

\section{Isolation of Clostridium perfringens}

One gm of fecal material diluted by adding $9 \mathrm{ml}$ of sterilized normal saline then one loopful was plated on sheep blood agar and incubated at $37^{\circ} \mathrm{C}$ for $24 \mathrm{hrs}$ under strict anaerobic conditions (Anaerobic Jar with a gas pack system). The presumptive detection of isolated bacteria was carried out by Gram staining, capsule staining and cultural characteristics of bacteria in special fluid media such as F Robinson Cooked meat medium, the confirmed test is performed by the detection of motility and gelatin liquefaction.

\section{Results}

Isolation and identification of Clostridium perfringens from fecal samples

Clostridium perfringens isolated and identificated from all collected fecal samples of wild animal as shown in Table 1. The Clostridium perfringens identified by its characteristic growth on blood agar its appear $\beta$-haemolytic colonies with double zone of haemolysis was observed Figures 1 and 2.

\section{Discussion}

Clostridium perfringens is a part of the normal intestinal flora of humans and animals [9-12], Although under certain conditions, $C$. perfringens becomes harmful and caused a disease therefore this is the first report for isolation and identified of, C. perfringens in wild zoo animal in Iraq. The positive $C$. perfringens results from wild zoo animals suggesting that $C$. perfringens is commonly part of the microbiota of



Figure 1: Clostridium perfringens on sheep blood agar appear gray colony, flate round, $\beta$-haemolytic colonies.

*Corresponding author: Aseel M Hamzah, Zoonotic Diseases Unit, College of Veterinary Medicine, Baghdad University, Baghdad, Iraq, Tel: 07400188261; E-mail: Aseelm30@yahoo.com

Received August 07, 2017; Accepted September 04, 2017; Published September 05, 2017

Citation: Hamzah AM (2017) Isolation of Clostridium $p$ Fecal Sample of Zoo Animals in Iraq. J Vet Sci Technol 8: 469. doi: 10.4172/2157-7579.1000469

Copyright: () 2017 Hamzah AM. This is an open-access article distributed under the terms of the Creative Commons Attribution License, which permits unrestricted use, distribution, and reproduction in any medium, provided the original author and source are credited. 


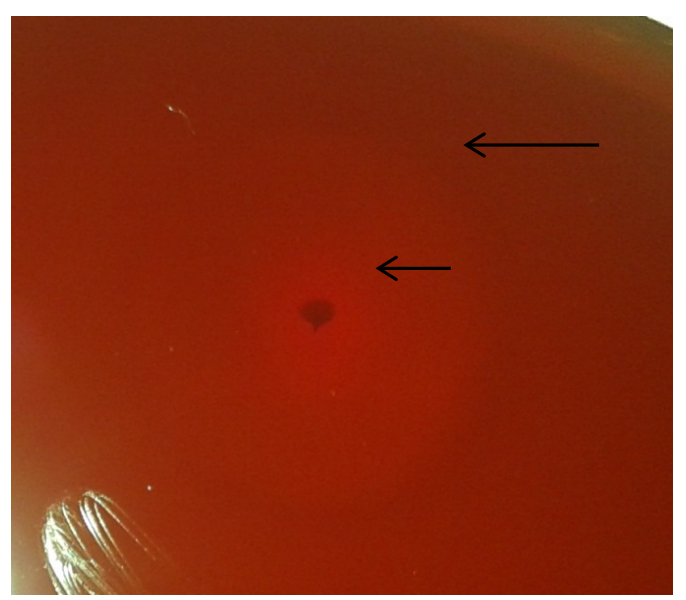

Figure 2: Clostridium perfringens single isolated colony showed double zone of heamolysis.

\begin{tabular}{|c|c|c|}
\hline Animal species & Number of fecal samples & Clostridium perfringens \\
\hline Bear & 10 & + \\
\hline Deer & 9 & + \\
\hline Pony & 7 & + \\
\hline Lion & 22 & + \\
\hline Elk & 8 & + \\
\hline Dog & 8 & + \\
\hline Horse & 12 & + \\
\hline Wildcat & 5 & + \\
\hline Zebra & 5 & + \\
\hline Siberia monkey & 9 & + \\
\hline Ostrich & 3 & + \\
\hline Baboon monkey & 9 & + \\
\hline Kangaroo & 1 & + \\
\hline wolf & 5 & + \\
\hline Camel & 9 & + \\
\hline Fox & 6 & + \\
\hline Porcupine & 5 & + \\
\hline lama & 6 & + \\
\hline goat & 8 & + \\
\hline jaguar & 7 & + \\
\hline chicken & 6 & + \\
\hline Hyena & 8 & + \\
\hline
\end{tabular}

Table 1: Isolation of Clostridium perfringens from fecal samples of different species of wild animals. these animals, as would be suspected. From the data of the present study, the distribution of $C$. perfringens among wild zoo animals needed additional studies must be carried out with specific primers to detect $C$. perfringens types and its toxins.

\section{Acknowledgements}

The authors wish to thank veterinarian staff and workers of Al-zawraa Zoo for their help.

\section{References}

1. Hamzah AM, Hussein AM, Khalef JM (2013) Isolation of Escherichia col 0157: H7 strain from fecal samples of zoo animal. The Scientific World J 2013 843968.

2. Stirling J, Griffith M, Dooley JS, Goldsmith CE, Loughrey A, et al. (2008) Zoonoses associated with petting farms and open zoos. Vector-Borne Zoonotic Dis 8: 85-92.

3. Hollamby S, Sikarskie JG, Stuht J (2003) Survey of peafowl (Pavo cristatus) for potential pathogens at three Michigan zoos. J Zoo Wildl Med 34: 375-379.

4. Álvarez-Pérez S, Blanco JL, Martínez-Nevado E, Peláez T, Harmanus C, et al (2014) Shedding of Clostridium difficile PCR ribotype 078 by zoo animals, and report of an unstable metronidazole-resistant isolate from a zebra foal (Equus quagga burchellii). Vet Microbiol 169: 218-222.

5. Silva RO, D'Elia ML, Teixeira ÉP, Pereira PL, de Magalhães Soares DF, et al. (2014) Clostridium difficile and Clostridium perfringens from wild carnivore species in Brazil. Anaerobe 28: 207-211.

6. Garmory HS, Chanter N, French NP, Bueschel D, Songer JG, et al. (2000) Occurrence of Clostridium perfringens $\beta 2$-toxin amongst animals, determined using genotyping and subtyping PCR assays. Epidemiol Infect 124: 61-67.

7. Weese JS, Staempfli HR, Prescott JF, Kruth SA, Greenwood SJ, et al. (2001) The roles of Clostridium difficile and enterotoxigenic Clostridium perfringens in diarrhea in dogs. $\mathrm{J}$ of Vet Intern Med 15: 374-378.

8. Weese JS, Staempfli HR, Prescott JF (2001) A prospective study of the roles of Clostridium difficile and enterotoxigenic Clostridium perfringens in equine diarrhoea. Equine Vet J 33: 403-409.

9. Songer JG, Uzal FA (2005) Clostridial enteric infections in pigs. J Vet Diagn Invest 17: 528-536.

10. Goldstein MR, Kruth SA, Bersenas AM, Holowaychuk MK, Weese JS (2012) Detection and characterization of Clostridium perfringens in the feces of healthy and diarrheic dogs. Can J Vet Res 76: 161-165.

11. Silva Ros, Ribeiro MG, Palhares MS, Maranhao RPA, Borges AS, et al. (2013) Detection of $A / B$ toxin and isolation of Clostridium difficile and $C$. perfringens from foals. Equine Vet J 45: 671-675.

12. Wang RF, Cao WW, Cerniglia CE (1996) PCR detection and quantitation of predominant anaerobic bacteria in human and animal fecal samples. App Environ Microbiol 62: 1242-1247. 